\title{
THE ASSESSMENT OF THE SITUATION OF LISTED COMPANIES IN MACROSECTORS IN A BEAR MARKET - DURATION ANALYSIS MODELS
}

\author{
BEATA BIESZK-STOLORZ, IWONA MARKOWICZ \\ University of Szczecin, Faculty of Economics and Management, Department of Econometrics and \\ Statistics, Mickiewicza Street 64, 71-101 Szczecin, Poland \\ email: beatus@wneiz.pl, iwona.markowicz@wneiz.pl
}

\begin{abstract}
The aim of the article is the use methods of duration analysis to assess the fluctuations in the prices of shares of companies listed on the Stock Exchange in Warsaw during the bear market in 2011 and over the next two years. The specific objectives of this study are as follows: the assessment of risk and intensity of the drop in stock prices in individual macrosectors in 2011, the assessment of the odds and intensity of recovery by the end of 2013, the similarity analysis of the duration function for stock market macrosectors in the times of bear market and of recovery, comparison of the situation in the stock market macrosectors in the observed period of the bear market and during the financial crisis of 2008-2009. The analysis is conducted by means of the logit model, Kaplan-Meier estimator, Cox regression model. The hypotheses have been set that the 2011 downturn strongly affected the financials macrosector, the price fluctuations in the macrosectors during the analysed bear market and crisis were similar. The study is based on the data of 378 companies (listed in the whole period under analysis) that are grouped in 3 macrosectors: industry, finance, services.
\end{abstract}

Key words: Warsaw Stock Exchange, listed companies' shares, bears market, macrosectors, duration analysis

JEL Codes: C10, C14, C41, G01

DOI: 10.15611/amse.2017.20.02

\section{Introduction}

The period 2008-2009 has been termed the period of the global financial crisis. The crisis affected the economies of many countries, including Poland. The effects of the crisis were visible on the Warsaw Stock Exchange. Table 1 presents rates of return (\%) on the WIG in 2005-2015. The maximum drop of the WIG values, comprising the companies listed on the Warsaw Stock Exchange main market, was in 2008. The next year with the negative rates of return on the WIG was 2011. Record trading in shares and derivatives was recorded that year, which indicated a rise in the activity of stock market investors. Unfortunately, the drop in company values in the second half of 2011 resulted in the fall of the WIG value by $20.8 \%$.

An interesting way of identifying the financial crisis has been presented by Olbryś and Majewska (2014). She used Pagan-Sossounov framework for analyzing bear and bull markets to determine the crisis stages basing on the analysis of monthly logarithmic rates of return on the main indexes of the Warsaw Stock Exchange, i.e. WIG and of the New York Stock Exchange, i.e. S\&P500. According to the definition of boom/slump, throughout their duration, an adequately large (of at least $20 \%$ ) rise/fall of values must take place in the sequence of quotations, which means that the amplitude of the boom is more than or equal 0.18 , while the 
amplitude of the slump is less than or equal -0.22 . The period of 2011 slump was not as spectacular as the 2007-2009 one, yet WIG dropped by at least 20\% (27\% from April 7 to September 23, 2011), S\&P500 dropped by at least 20\% too (20\% from April to October 2011).

Table 1: Rates of return on the WIG in 2005-2015 (\%).

\begin{tabular}{cccc}
\hline Year & Rates of return & Year & Rates of return \\
\hline 2006 & 41.6 & 2011 & -20.83 \\
2007 & 10.39 & 2012 & 26.24 \\
2008 & -51.07 & 2013 & 8.06 \\
2009 & 46.85 & 2014 & 0.26 \\
2010 & 18.77 & 2015 & -9.62 \\
\hline
\end{tabular}

Source: http://www.gpw.pl/analizy_i_statystyki.

The main aim of the article is to analyze the fluctuations in the prices of shares of companies listed on the Stock Exchange in Warsaw during the bear market in 2011 and over the next two years. The specific objectives of this study are as follows:

- the assessment of risk of the decrease in 2011 and odds of the increase by the end of 2013 in stock prices in individual macrosectors (objective 1),

- the assessment of intensity of the decrease in 2011 and intensity of the increase by the end of 2013 in stock prices in individual macrosectors (objective 2),

- the similarity analysis of the duration function for stock market macrosectors in the times of bear market and of recovery (objective 3),

- comparison of the situation in the stock market macrosectors in the observed period of the bear market and during the financial crisis of 2008-2009 (objective 4).

The hypotheses have been set that:

- the 2011 downturn strongly affected the financials macrosector (hypothesis 1),

- the impact of the bear market and the crisis on stock prices of companies in macrosectors were similar (hypothesis 2).

In the period from April $7^{\text {th }} 2011$ to September $23^{\text {rd }} 2011$ WIG index fell by about $30 \%$ (minimum limit). Next, the recovery was observed, or increase of the stock prices by $40 \%$ (maximum limit) from its minimum. The risk of a 30\% decrease in three macrosectors and the odds of a $40 \%$ increase from the bottom price (of each company) are examined by means of the logit model. The interpretation of the Cox regression model parameters allowed for the assessment of the price decrease intensity in the analyzed macrosectors as well as the intensity of recovery. In the analysis the authors use the explanatory variable coding $-1 ; 0 ; 1$ that enables them to compare the risk, odds and intensity in the analyzed macrosectors with the respective average risk, odds and intensity in macrosectors in general. The study is based on the data of 378 companies (listed in the whole period under analysis) that are grouped in 3 macrosectors. Their closing prices are taken into account.

\section{Data and Methodology of Research}

The data of companies listed on the Warsaw Stock Exchange were used in the study. The observation of share prices started in 2011 (the bear market year) and ended in 2013. The surveyed 378 companies were grouped into 3 macrosectors (http://www.gpw.pl/wskazniki_sektorow):

- industry - including sectors: construction, chemicals, wood \& paper, electroengineering, pharmaceutical, building materials, light, metals, automobiles, oil \& gas, other industries, food, basic materials, plastics materials, 
- finance - including sectors: banking, developers, finance other, capital market,

- services - including sectors: energetics, retail trade, wholesale trade, hotels \& restaurants, it, media, telecom, other services.

Logit model, proportional hazard model and Kaplan-Meier estimator were used in the study.

The analysis of the downside risk followed by recovery is conducted by means of the logit model written (Kleinbaum and Klein, 2002; Gruszczyński, 2012; Markowicz, 2012; BieszkStolorz and Markowicz, 2014):

$$
\operatorname{logit}(p)=\ln \left(\frac{p}{1-p}\right)=\alpha_{0}+\sum_{i=1}^{m} \alpha_{i} x_{i}
$$

where:

$p=\mathrm{P}\left(Y=1 \mid x_{1}, x_{2}, \ldots, x_{m}\right)-$ conditional probability of an event to occur,

$x_{1}, x_{2}, \ldots, x_{m}-$ explanatory variables,

$\alpha_{0}, \alpha_{1}, \alpha_{2}, \ldots, \alpha_{m}$ - model coefficients.

Theoretical bases were widely discussed by Hosmer and Lemeshow (2000), Kleinbaum and Klein (2002), Cramer (2002), while Agresti (2002) and Wiśniewski (2011) pointed it out among the researching methods of quality phenomena.

The analysis of the intensity of the price decrease and increase is conducted by means of the Cox model (Cox and Oakes, 1984), which is also called the model of proportionate hazards (Bieszk-Stolorz and Markowicz, 2012; Landmesser, 2013). The model can be written:

$$
h\left(t: x_{1}, x_{2}, \ldots, x_{n}\right)=h_{0}(t) \exp \left(\beta_{1} x_{1}+\beta_{2} x_{2}+\ldots+\beta_{n} x_{n}\right)
$$

where:

$h\left(t: x_{1}, x_{2}, \ldots, x_{n}\right)$ - hazard with the data of $n$ independent variables $x_{1}, x_{2}, \ldots, x_{n}$ and the adequate survival time $t$,

$h_{0}(t)$ - reference hazard or baseline hazard,

$\beta_{1}, \beta_{2}, \ldots, \beta_{n}$ - model coefficients,

$t$ - the time of observation.

The probability for the event not to occur is estimated by means of the Kaplan-Meier survival function (Kaplan and Meier, 1958; Kleinbaum and Klein, 2012; Markowicz and Stolorz, 2015):

$$
\hat{S}\left(t_{i}\right)=\prod_{j=1}^{i}\left(1-\frac{d_{j}}{n_{j}}\right) \quad \text { for } i=1, \ldots, k,
$$

where:

$t_{i}$ - the point in time when at least one event occurred, $t_{1}<t_{2}<<t_{k}, t_{0}=0$,

$d_{i}$ - the number of events in the time $t_{i}$,

$n_{i}$ - number of units under observation in the time $t_{i}, n_{i}=n_{i-1}-d_{i-1}-z_{i-1}$,

$z_{i}$ - number of observations censored in the time $t_{i}$.

The significance of differences in survival curves can be compared by means of adequate tests (Gehan, 1965a; Gehan, 1965b; Domański et al., 2014). Several tests were proposed for the comparison of two or more survival curves (e.g. log-rank, Gehan test, Tarone-Ware test, Peto-Peto test). However, the power of these tests differs in particular situations. Little attention is drawn in literature to the comparison of their applicability (Lin and Wang, 2004; Jurkiewicz and Wycinka, 2011). The log-rank test was used in the study $\left(\mathrm{H}_{0}: S_{1}(t)=S_{2}(t)\right.$, $\left.\mathrm{H}_{1}: S_{1}(t) \neq S_{2}(t)\right)$. 
The logistic model was used to address the first specific objective. The binomial variable $\mathrm{Y}$ adopts the value of 1 when a specified event has occurred (at least $30 \%$ fall $/ 40 \%$ rise in the stock price). Otherwise the value is the variable is 0 . The explanatory variables are dummy variables describing macrosectors. Different ways of defining such variables are used in socio-economic research. The choice of a coding method implies a way of defining the reference group (Hosmer and Lemeshow, 2000; Markowicz and Stolorz, 2009). The binary (0-1) coding is often used. If that be the case, one of the subgroups becomes a reference group. In this study the $-1 ; 0 ; 1$ coding is used (quasi-experimental coding) to compare the risk of the price decrease and odds of the price increase in a given macrosector with the average risk/odds. The comparison of the risks of decrease and the odds of increase is made by means of $\exp \left(\alpha_{i}\right)$, called the risk ratio $R R$ or the odds ratio $O R$. The authors observe the $30 \%$ slump from maximum to minimum prices in 2011 and the recovery from the minimum price in 2011 to its rise up to $40 \%$ or by the end of the observation on 31 December 2013.

The Cox proportional hazards model was used to address the second specific objective. Proportionality of hazard was analysed by means of the graphical method (Markowicz and Stolorz, 2012; Kleinbaum and Klein, 2012). As with the logit model, the $-1 ; 0 ; 1$ encoding was used. The time of the price decrease is counted from the moment when the company prices peaked in 2011 to the moment when they fell by 30\%. If the fall did not take place, the observation is considered censored. The time of the price recovery starts when the company price reached its minimum in 2011 and ends at the moment when it rose by $40 \%$ increase. If such a top value had not been reached by the end of 2013, the observation is considered censored. In order to interpret the intensity of the decrease/increase of the company stock prices, the hazard ratios $\left(H R=\exp \left(\beta_{i}\right)\right)$ for 3 macrosectors are determined.

The third specific objective was addressed by means of the Kaplan-Meier and log-rank test. The probabilities of not achieving a 30\% decrease and a $40 \%$ increase in individual macrosectors have been examined and compared.

Table 2 shows the number of the surveyed companies in general and the companies that have achieved a $30 \%$ decrease in share prices in 2011 , a $40 \%$ increase in share prices by the end of 2013.

Table 2: Rates of return on the WIG in 2005-2015 (\%).

\begin{tabular}{cccc}
\hline \multirow{2}{*}{ Macrosectors } & \multirow{2}{*}{ Number of listed companies } & \multicolumn{2}{c}{ Complete observations (percentage) } \\
\cline { 3 - 4 } & & Decrease $30 \%$ & Increase $40 \%$ \\
\hline Industry & 160 & $141(88.1 \%)$ & $136(85.0 \%)$ \\
Finance & 78 & $72(92.3 \%)$ & $69(88.5 \%)$ \\
Services & 140 & $117(83.6 \%)$ & $114(81.4 \%)$ \\
Total & 378 & $33087.3 \%)$ & $319(84.4 \%)$ \\
\hline
\end{tabular}

Source: own study.

\section{Research Results}

The first stage of the analysis consists of the assessment of the relative risk of the decrease and relative odds of the increase of the stock prices in macrosectors. To this end the logit model (1) are used. Figure 1 shows the risk and odds ratios. Their value bigger than 1 (bold line in Fig. 1) shows that the risk decrease/the odds increase of prices in a given macrosector is higher than the average risk/odds. The highest, above the average, risk was seen by the financials (1.5625). The relative risk for the industrials was close to the average (0.9663), while the services observed the lowest risk (0.6624). The highest, above average, odds was seen by the financials (1.3325). The relative odds seen by the industrials was close to the 
average (0.9849), while the macrosector of services faced the lowest odds of the stock prices to recover $(0.7620)$.

The second stage of the study comprise the assessment of the relative intensity of the decrease and the increase of stock prices in the macrosectors (Fig. 2). To this end the Cox regression model (2) are used. The intensity provides information about the probability of the price decrease/increase in a unit of time, while the relative intensity is a comparison of a given group's intensity with the one determined for the reference group (in this study, with mean). The obtained results confirm the situation of the analyzed macrosectors. It was the financial companies that most strongly responded to the downturn (1.2901). The intensities of the decrease below the average were seen by the industrials (0.9395) and services (0.8250). It was the financial companies that most strongly making up for losses (1.1590). The intensities of the increase below the average were seen by the industrials $(0.9870)$ and services $(0.8742)$.

Figure 1: Risk ratio of the decrease (30\%) and odds ratio of the increase $(40 \%)$ of the stock prices by macrosectors.

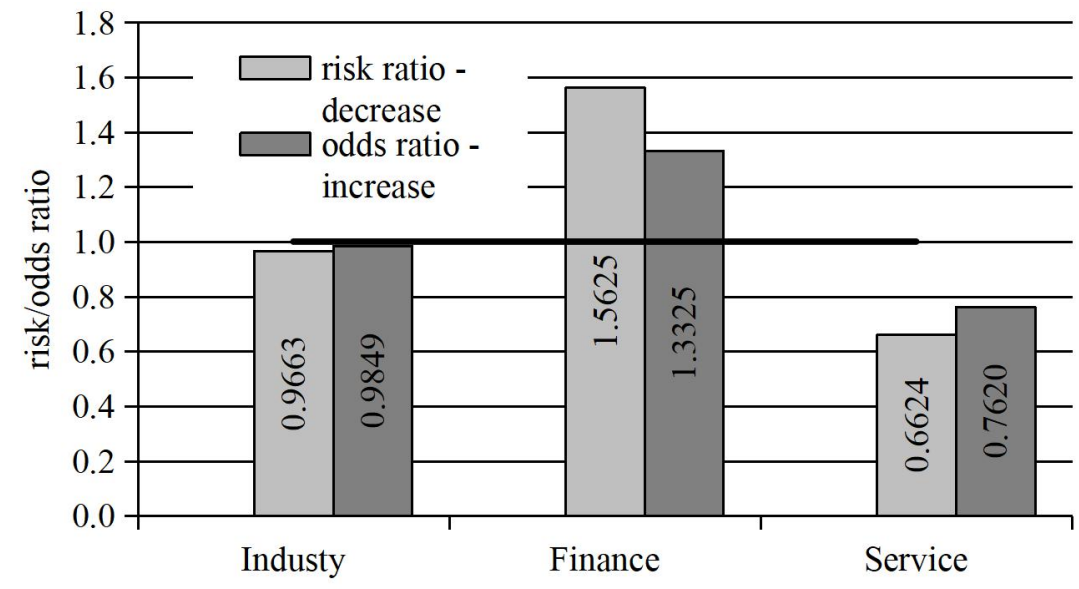

Source: own study.

Figure 2: Hazard ratios of the decrease and the increase of stock prices by macrosectors.

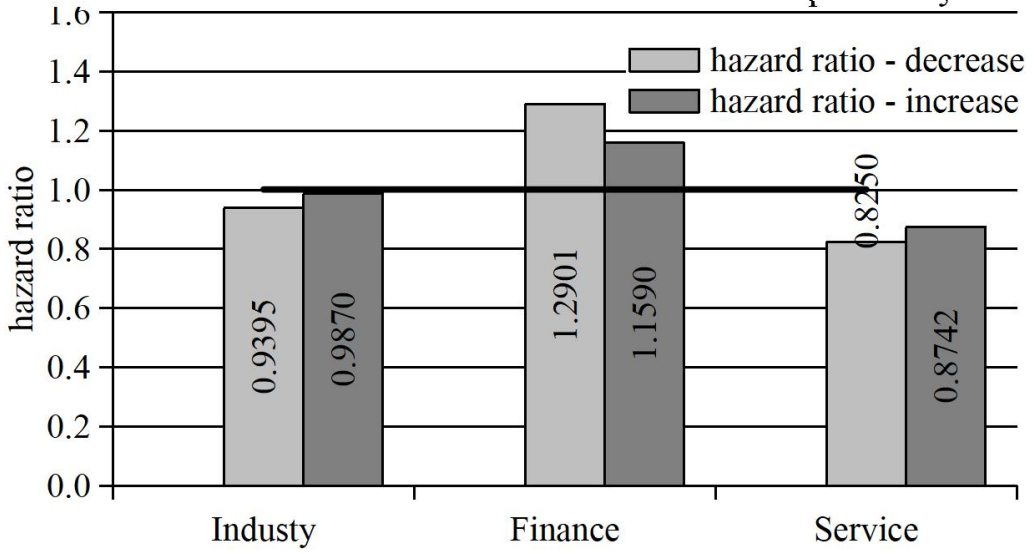

Source: own study.

In the third stage the analysis focuses on the probability of failing to reach a $30 \%$ decrease and $40 \%$ recovery of stock prices in the individual macrosectors (objective 3 ). The duration curves (Fig. 3-4) are determined by means of the Kaplan-Meier estimator (3). The hypothesis of the similarity of the duration functions for the pairs of macrosectors is verified with the logrank test (Table 3). The results imply that during the price decline the progression of the financials function differed from the other macrosectors. At the time of price recovery, however, the progress duration functions were similar in all the macrosectors. 
Figure 3: Kaplan-Meier estimator for macrosectors during the decrease in shares prices of companies.

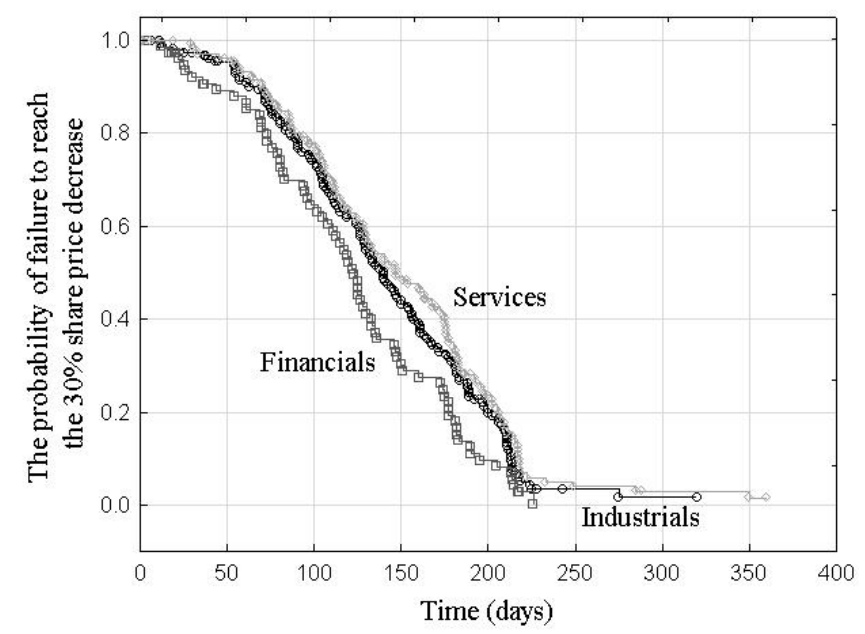

Source: own study.

Figure 4: Kaplan-Meier estimator for macrosectors during the increase in shares prices of companies.

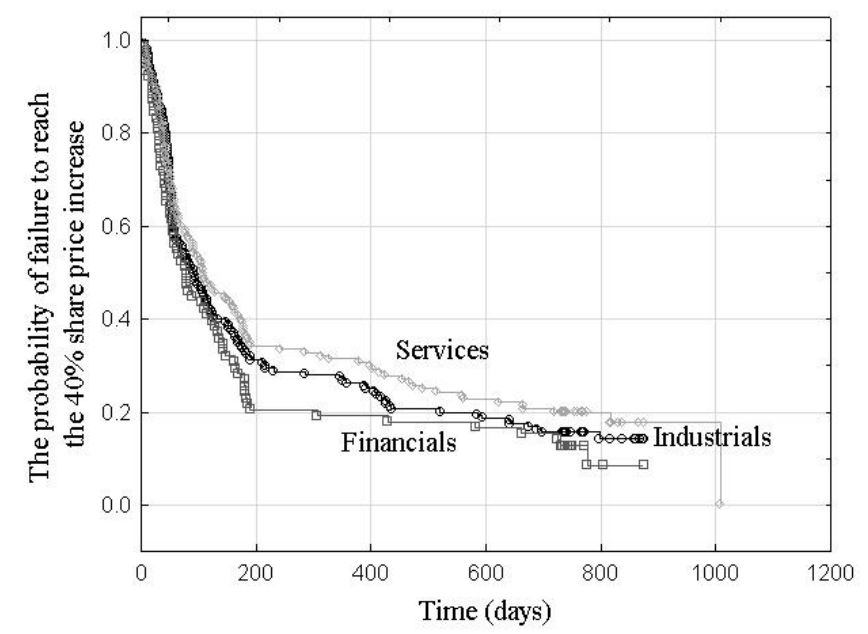

Source: own study.

Table 3: The results of log-rank test for pairs macrosectors during the decrease and increase in shares prices.

\begin{tabular}{ccc}
\hline \multirow{2}{*}{ Macrosectors pairs } & \multicolumn{2}{c}{ Test $(p$-value $)$} \\
\cline { 2 - 3 } & Decrease 30\% & Increase 40\% \\
\hline Industry-Finance & $-2.0501(p=\mathbf{0 . 0 4 0 4})$ & $-1.0670(p=0.2846)$ \\
Industry-Service & $1.0200(p=0.3077)$ & $0.9677(p=0.3332)$ \\
Finance-Service & $2.8340(p=\mathbf{0 . 0 0 4 6})$ & $1.7901(p=0.0734)$ \\
\hline
\end{tabular}

Source: own study.

The fourth stage of this study, and its conclusion, is the comparison of the situation in the stock market macrosectors in the observed period of the market downturn and throughout the financial crisis of 2008-2009 (objective 4). Previous studies by the authors examined fluctuations in share prices during the crisis. The results of those and the current studies have 
made it possible to compare the strength of stock price reaction to the situation on the Polish market. The demonstration of the values of stock price decrease line risks and stock price increase odds in a form of a diagram helps to identify the areas that are characteristic of the macrosectors situation in the bear market and in the subsequent bull market (Fig. 4). When the intersection of the axes is set at 1 for both the price decrease risk and the price increase odds, we can distinguish four areas:

1) „low - low"; low risk of price decrease and low odds of price increase,

2) "high - high"; high risk of price decrease and high odds of price increase,

3) „low - high"; low risk of price decrease followed by high odds of price increase,

4) „high - low"; high risk of price decrease followed by low odds of price increase.

The first area indicates the weak response to the downturn (small price decrease followed by small price increase). The third area is also characterized with low risk of the price decrease but the price increase odds ratio is higher than the average. These two areas show that losses to recover from are not significant. The second field signals a strong reaction to the bear market and the high odds of increase. The worst situation is represented by the fourth field where the risk of the price decrease is high and the odds of the subsequent recovery are below the average. Figure 4 shows the situation of stock market macrosectors at the time of the analysed 2011 bear market as well as during the financial crisis of 2008-2009. The situation of the macrosectors can be characterized as follows:

- services - situation during the bear market and the crisis was almost identical; the location in the first area (low-low) indicates weak response to the downward stock market trends,

- financials - the location in the second area (high-high) suggests strong response to the crisis periods, but also the considerable odds of recovery; the situation during the bear market was slightly better than during the crisis,

- industrials - during the crisis the macrosector was located in the third, best area (high recovery odds despite low risk of price decrease), while during the bear market it moved to the first area and was located in the close vicinity of the intersection of the axes (value 1 and 1), which implies the absence of response to the stock prices movements.

Figure 5: Ratios: decrease risk and increase odds of share prices by macrosectors - the intersection of the axes $(1,1)$.

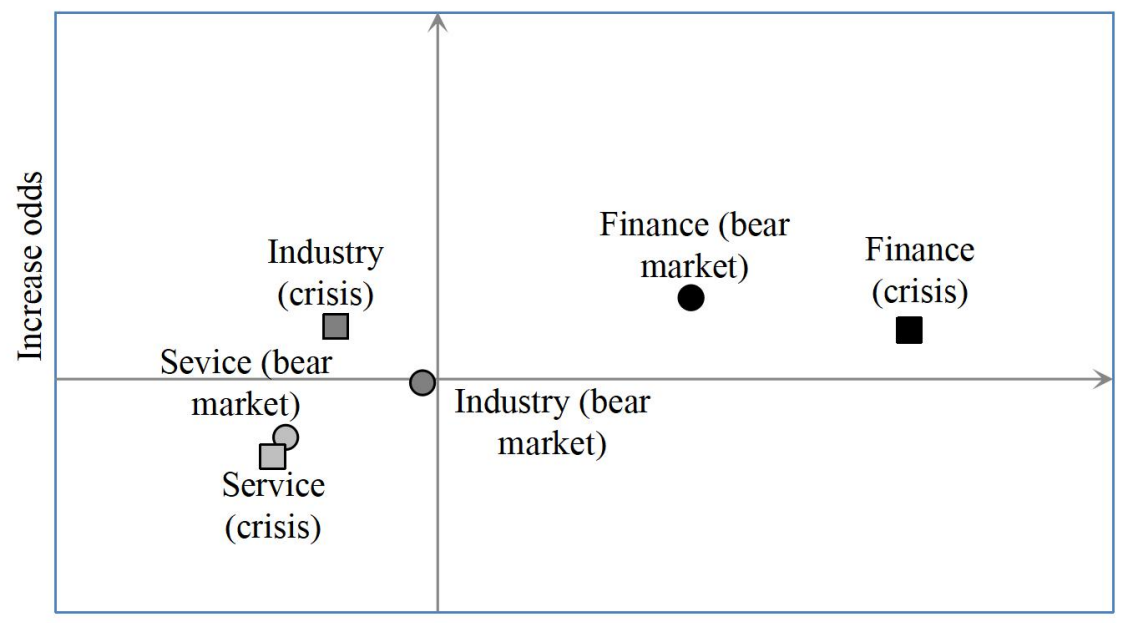

Decrease risk

Source: own study. 


\section{Conclusion}

The article presents the findings of the analysis of macrosector stock price movements of WSE companies in the time of the 2011 bear market and over two subsequent years. The study is divided into stages pursuant to the adopted four specific objectives: the assessment of risk of the decrease in 2011 and odds of the increase by the end of 2013 in stock prices in individual macrosectors (objective 1), the assessment of intensity of the decrease in 2011 and intensity of the increase by the end of 2013 in stock prices in individual macrosectors (objective 2), the similarity analysis of the duration functions for individual stock market macrosectors in the time of decrease and increase (objective 3), and, finally, the comparison of the situation in the stock market macrosectors in the time of the 2011 bear market and the financial crisis of 2008-2009 (objective 4).

The first hypothesis (the effect of the 2011 bear market on the macrosector of financials was particularly strong) has been confirmed, because the financials faced both the high risk of price decrease and high odds of their increase. The analysis of the progression of the KaplanMeier curves as well as the results of the log-rank test indicate more rapid 30\% decrease in prices in the macrosector of financials than in the remaining macrosectors.

The hypothesis about a similar situation of macrosectors during the financial crisis and the bear market has not been confirmed in the case of the financials and the industrials. The situation of the financials during the downturn market was better than in the time of the crisis, while in the case of the industrials - it was worse (taking into consideration the average situation of the listed companies at a given time).

Applying the methods of duration analysis indicates the originality of the article. They stem from demographics and are now used in other fields of science. They can be used successfully in capital market analyses. The duration analysis methods were used in the article to examine the bear market. The aim of the authors' next research project will be the analysis of a bull market.

\section{References}

[1] Agresti, A. 2002. Categorial data analysis. Second edition. Hoboken, New Jersey: John Wiley Sons. ISBN: 9780471360933.

[2] Bieszk-Stolorz, B., Markowicz, I. 2011. Wykorzystanie modelu proporcjonalnego hazardu Coxa do oceny czasu od spadku cen akcji spółek giełdowych w okresie kryzysu finansowego do ich wzrostu. Prace Naukowe Uniwersytetu Ekonomicznego we Wrocławiu, vol. 183, pp. 47-54.

[3] Bieszk-Stolorz, B., Markowicz, I. 2012. Modele regresji Coxa w analizie bezrobocia. Warszawa: CeDeWu. ISBN: 978-83-7556-474-7.

[4] Bieszk-Stolorz, B., Markowicz, I. 2014. Economical activity of the Polish population. Folia Oeconomica Stetinensia vol. 14(22), pp. 198-210. DOI: 10.1515/foli-2015-0007.

[5] Bieszk-Stolorz, B., Markowicz, I. 2015. Application of survival analysis in efficiency evaluation of professional effectiveness enhancement programme. Acta Universitatis Lodziensis. Folia Oeconomica, vol. 1(311), pp. 85-91. DOI: 10.18778/0208-6018.311.09.

[6] Cox, D.R., Oakes, D. 1984. Analysis of survival data. London: Chapman and Hall. ISBN: 9780412244902.

[7] Cramer, J.S. 2002. The origins of logistic regression. Working Paper. Tinbergen Institute, No. 119/4. [cit. 15-09-2012] https://papers.tinbergen.nl/02119.pdf. 
[8] Domański, Cz., Pekasiewicz, D., Baszczyńska, A., Witaszczyk, A. 2014. Testy statystyczne w procesie podejmowania decyzji. Łódź: Wydawnictwo Uniwersytetu Łódzkiego. ISBN: 9788379693580.

[9] Gehan, E.A. 1965a. A generalized two-sample Wilcoxon test for double-censored data. Biometrika, vol. 52, iss 3-4, pp. 650-653. DOI: 10.2307/2333721.

[10]Gehan, E.A. 1965b. A generalized Wilcoxon test for comparing arbitrarily singlycensored samples. Biometrika, vol. 52, iss. 1-2, pp. 203-223. DOI: 10.2307/2333825.

[11]Gruszczyński, M. (ed.) 2012. Mikroekonometria. Modele i metody analizy danych indywidualnych. Warszawa: Oficyna, Wolters Kluwer S.A. ISBN: 978-83-264-5184-3.

[12]Hosmer, D.W., Lemeshow, S. 2000. Applied logistic regression. New York: John Wiley \& Sons, Inc. ISBN: 9780471722144.

[13]http://biznes.pl/gielda/profile/swiat/sp-500-us,402,2,6,profile-wykresy-s.html. [cit. 17-112014].

[14]http://www.gpw.pl/analizy_i_statystyki. [cit. 07-08-2016].

[15] http://www.gpw.pl/wskazniki_sektorow. [cit. 08-08-2016].

[16] Jurkiewicz, T., Wycinka, E. 2011. Significance tests of differences between two crossing survival curves for small samples. Acta Universitatis Lodziensis. Folia Oeconomica vol. 255, pp. 107-114.

[17]Kaplan, E.L., Meier, P. 1958. Nonparametric estimation from incomplete observations. Journal of the American Statistical Association, vol. 53, iss. 282, pp. 457-481. DOI: 10.1080/01621459.1958.10501452.

[18]Kleinbaum, D.G., Klein, M. 2002. Logistic regression. A self-learning text. New York: Springer-Verlag. ISBN: 9780387953977.

[19] Kleinbaum, D.G., Klein, M. 2012. Survival analysis. A self-learning text. Thrid edition. New York: Springer. DOI: http://dx.doi.org/10.1007/978-1-4419-6646-9.

[20]Landmesser, J. 2013. Wykorzystanie metod analizy czasu trwania do badania aktywności ekonomicznej ludności w Polsce. Warszawa: Wydawnictwo SGGW. ISBN: 978-837583-425-3.

[21]Lin, X., Wang, H. 2004. A new testing approach for comparing the overall homogeneity of survival curves. Biometrical Journal, Vol. 46, iss. 5, pp 489-496. DOI: 10.1002/bimj.200310053.

[22] Markowicz, I. 2012. Application of logistic regression in firmography. Actual Problems of Economics, vol 5, iss. 2, pp. 180-190.

[23] Markowicz, I., Stolorz, B. 2009. Interpretation of parameters of the logistic regression and ways of coding of explanatory variables. Polish Journal of Environmental Studies, vol. 18, iss. 3B, pp. 252-256.

[24] Olbryś, J., Majewska, E. 2014. Identyfikacja okresu kryzysu z wykorzystaniem procedury diagnozowania stanów rynku. Zeszyty Naukowe Uniwersytetu Szczecińskiego. Finanse, Rynki Finansowe, Ubezpieczenia, vol. 802, iss. 65, pp. 699-710.

[25]Wiśniewski, J.W. 2011. Dilemmas of economic measurements in weak scales. Folia Oeconomica Stetinensia, vol. 10(18), pp. 50-59. DOI: 10.2478/v10031-011-0045-7. 
20th International Scientific Conference AMSE

Applications of Mathematics and Statistics in Economics 2017

Szklarska Poręba, Poland

30 August 2017 - 3 September 2017 